\title{
PENGARUH KOMPETENSI DUTA WISATA TERHADAP AKSELERASI PROMOSI AGROWISATA SAWAH SOLOK
}

\section{The Effect of Tourism Ambassador Competence for the Acceleration of Promoting Agro-tourism in Sawah Solok}

\author{
Ilhamda El Zuhri*) dan Ninuk Purnaningsih
}

Departemen Sains Komunikasi dan Pengembangan Masyarakat, Fakultas Ekologi Manusia, Institut Pertanian Bogor, Dramaga, Bogor 16680, Indonesia

*)E-mail: ilhamda_iin24@apps.ipb.ac.id ; npurnaningsih@gmail.com

Diterima: 06-11-2021 | Disetujui: 14-10-2021 | Publikasi online: 25-10-2021

\begin{abstract}
Beauty pageant events currently have a fairly large existence in the midst of Indonesian society. The number of events for the selection of Putri Indonesia, Cultural Ambassadors, and Tourism Ambassadors at the national and regional levels makes competency measurement indicators and factors that influence contestants in carrying out their duties important. This study aims to see the influence between individual characteristic, competence and external factors on tourism ambassadors on their performance in carrying out their role to promote Sawah Solok Agrotourism. This research using a quantitative approach supported by qualitative approach. This is an explanatory research with 30 respondents using regression analyses. The result of this research show that generation, communication skill, the support of community and local government influence the tourism ambassador in promoting Sawah Solok Agro-tourism.
\end{abstract}

Keywords: Sawah Solok Agro-tourism, tourism ambassador, tourism promotion,

\section{ABSTRAK}

Ajang kecantikan saat ini memiliki eksistensi yang cukup besar di tengah masyarakat Indonesia. Banyaknya ajang pemilihan Putri Indonesia, Duta Budaya, hingga Duta Wisata di tingkat nasional dan daerah membuat indikator pengukuran kompetensi dan faktor yang memengaruhi kontestan dalam melaksanakan tugasnya menjadi penting. Penelitian ini bertujuan untuk melihat pengaruh karakteristik individu, kompetensi duta wisata, dan faktor eksternal pada duta wisata terhadap performanya dalam melaksanakan promosi Agrowisata Sawah Solok. Penelitian ini menggunakan pendekatan kuantitatif yang didukung dengan pendekatan kualitatif. Penelitian ini merupakan explanatory research dengan jumlah responden sebanyak 30 orang yang menggunakan uji regresi. Hasil penelitian ini menunjukkan bahwa faktor yang memengaruhi duta wisata dalam promosi Agrowisata Sawah Solok adalah angkatan, kemampuan komunikasi, dukungan komunitas, dan dukungan pemerintah.

Kata kunci: Agrowisata Sawah Solok, duta wisata, promosi wisata

\section{PENDAHULUAN}

Content from this work may be used under the terms of the Creative Commons Attribution-ShareAlike 4.0 International. Any further distribution of this work must maintain attribution to the author(s) and the title of the work, journal citation and DOI.

Published under Department of Communication and Community Development Science, IPB University E-ISSN: 2442-4102 |P-ISSN: 1693-3699 
Ajang kecantikan merupakan kompetisi pemilihan seorang putri dan putra serta duta dari sektor tertentu dengan fokus utama adalah keindahan fisik, kemampuan pengetahuan, dan kepribadian. Hermansyah (2011) menyebutkan bahwa Indonesia mulai aktif mengikuti kontes ajang kecantikan pada tahun 1967, ketika pertama kalinya Miss Indonesia diadakan. Salah satu kontes kecantikan nasional yang diadakan tiap tahun adalah Putri Indonesia, pemenangnya akan menjadi wakil Indonesia pada kegiatan-kegiatan yang bertaraf internasional dan ikut serta memajukan komoditas-komoditas ekspor, pariwisata dan budaya Indonesia. Di Indonesia sendiri banyak sekali kontes kecantikan mulai dari Putri Indonesia, Miss Indonesia, Putri Pariwisata Indonesia dan ajang yang lainnya. Selanjutnya, untuk pemenang Putri Indonesia akan mengikuti ajang Miss Universe serta ajang lain untuk pemenang lainnya.

Pemilihan putra dan putri pariwisata Indonesia sebagian besar didahului oleh pemilihan dari provinsi, kabupaten dan kota masing-masing daerah. Banyak sebutan untuk ajang pemilihan duta wisata yang menyesuaikan dengan bahasa daerah masing-masing seperti di DKI Jakarta dengan sebutan duta wisata adalah abang none, Jawa Barat menyebut dengan mojang jajaka, pada Kabupaten Indragiri disebut dengan bujang dara, di Kota Palu disebut dengan Randa'a Ante Kalibasa, dan di Sumatera Barat disebut dengan Uda Uni Duta Wisata. Secara umum, duta wisata memiliki peran yang sama dengan praktisi public relations dalam mempromosikan pariwisata daerah. Hal ini dibuktikan oleh hasil penelitian Randa dan Achnes (2015) bahwa peran Uda Uni Duta Wisata ${ }^{1}$ dalam mempromosikan pariwisata dilaksanakan melalui sales promotion (penjualan langsung), public relations (hubungan masyarakat), dan menyebarkan informasi melalui word of mouth (informasi dari mulut ke mulut).

Sayangnya, maraknya ajang pemilihan duta dan kontes kecantikan di setiap daerah, tidak diiringi oleh dampak yang dirasakan oleh masyarakat dan pemerintah setelah pemilihan dilakukan. Berdasarkan penelitian dari Melasari et al. (2017) bahwa peranan Randa Kabilasa sebagai duta wisata Kota Palu dalam proses penyampaian informasi kepada wisatawan belum berjalan dengan baik. Hasil penelitian dari Agung dan Wijaya (2019) juga menjelaskan bahwa masyarakat umum yang belum pernah mengikuti salah satu program Paguyuban Sekargading sebagai duta wisata Kabupaten Batang, cenderung menganggap mereka hanya sebagai among tam $u^{2}$ dan masih mengikuti aktivitas dinas saja.

Menurut UU RI No 10 Tahun 2009 tentang Kepariwisataan, pariwisata adalah berbagai macam kegiatan wisata dan didukung berbagai fasilitas serta layanan yang disediakan oleh masyarakat, pengusaha, pemerintah, dan pemerintah daerah. Lebih lanjut, wisata adalah kegiatan perjalanan yang dilakukan oleh seseorang atau sekelompok orang dengan mengunjungi tempat tertentu untuk tujuan rekreasi, pengembangan pribadi, atau mempelajari keunikan daya tarik wisata yang dikunjungi dalam jangka waktu sementara. Oleh karena itu, semua pihak seperti masyarakat, pemerintah, serta duta wisata memiliki peran dalam pengembangan wisata.

Kota Solok adalah salah satu kota yang telah mengadakan pemilihan duta wisata sejak tahun 2003. Kota Solok yang memiliki banyak potensi wisata seperti wisata alam, kuliner, religi, dan wisata budaya. Salah satunya adalah Agrowisata Sawah Solok yang merupakan kombinasi area persawahan dengan sistem minapadi serta ditambah berbagai fasilitas untuk menunjang kenyamanan pengunjung. Destinasi Agrowisata Sawah Solok didirikan sejak tahun 2017 dan berhasil menarik minat wisatawan untuk menghabiskan waktu menikmati pemandangan, suasana yang asri serta dapat memancing dan memberi makan ikan. Adanya duta wisata diharapkan dapat meningkatkan promosi Agrowisata Sawah Solok.

\footnotetext{
${ }^{1}$ Penyebutan duta wisata di daerah Sumatera Barat menggunakan bahasa minang

${ }^{2}$ Penanti tamu acara besar
} 
Banyaknya ajang pageant dan pemilihan duta wisata hampir di setiap daerah Indonesia, membutuhkan panduan konkret tentang kompetensi yang harus dipenuhi agar kontestan terpilih dapat melaksanakan peran dan tugas yang diharapkan. Hal ini dipengaruhi oleh karakteristik individu, kompetensi individu duta wisata serta faktor eksternal. Karakteristik individu pada duta wisata meliputi usia, jenis kelamin, tingkat pendidikan, jenis pekerjaan, lama tinggal, angkatan, dan gelar duta wisata. Pengukuran kompetensi dapat dilihat dari slogan ajang pageant yang sudah mendunia, yaitu pengetahuan (brain), penampilan (beauty), sikap (behavior) serta dalam penelitian ini akan dilengkapi dengan pengukuran tingkat kemampuan komunikasi (communication skill). Performa duta wisata dalam melaksanakan tugasnya juga dipengaruhi oleh faktor yang berasal dari luar atau lingkungan eksternalnya. Faktor eksternal ini meliputi tingkat dukungan komunitas duta wisata dan tingkat dukungan pemerintah lokal. Tugas duta wisata dalam akselerasi promosi dapat diukur melalui frekuensi dan metode sales promotion (penjualan langsung), public relations (hubungan masyarakat), dan word of mouth (informasi dari mulut ke mulut). Oleh karena itu pertanyaan penelitian ini adalah sebagai berikut: (1) Bagaimana karakteristik responden yang terdiri atas usia, jenis kelamin, tingkat pendidikan, jenis pekerjaan, lama tinggal, angkatan, dan gelar dalam akselerasi promosi Agrowisata Sawah Solok?; (2) Bagaimana kompetensi duta wisata yang terdiri atas pengetahuan (brain), penampilan (beauty), sikap (behavior) dan kemampuan komunikasi (communication skill) dalam akselerasi promosi Agrowisata Sawah Solok?; (3) Bagaimana faktor eksternal yang terdiri atas tingkat dukungan komunitas dan pemerintah lokal pada duta wisata dalam akselerasi promosi Agrowisata Sawah Solok?; (4) Bagaimana akselerasi promosi Agrowisata Sawah Solok yang dilakukan oleh duta wisata?; dan (5) Bagaimana pengaruh karakteristik individu, kompetensi dan faktor eksternal duta wisata terhadap akselerasi promosi Agrowisata Sawah Solok?

\section{PENDEKATAN TEORITIS}

\section{Ajang Pageant atau Kontes Kecantikan}

Pageant atau biasa disebut kontes kecantikan merupakan ajang pemilihan perempuan atau lakilaki yang dianggap "cantik" berdasarkan standardisasi tertentu. Menurut Sari (2016) kontes kecantikan adalah sebuah kompetisi yang berfokus pada keindahan fisik kontestan, meskipun kontes seperti itu sering menggabungkan kepribadian, bakat, dan jawaban atas pertanyaan juri sebagai kriteria penilaian. Salah satu kontes kecantikan nasional yang diadakan tiap tahun adalah Putri Indonesia, pemenangnya akan menjadi wakil Indonesia pada kegiatan-kegiatan yang bertaraf internasional dan ikut serta memajukan komoditas-komoditas ekspor, pariwisata dan budaya Indonesia. Pemenang juga akan melakukan berbagai aksi sosial ke daerah-daerah yang membutuhkan untuk turut memberikan penghiburan dan bantuan.

\section{Duta Wisata}

Duta wisata adalah kontes pemilihan beberapa pemuda untuk membantu dinas pariwisata dalam mempromosikan wisata daerah. Menurut Oktarina (2015) duta wisata adalah pemilihan remaja berusia 16 tahun sampai dengan 26 tahun untuk menjadi citra teladan generasi muda yang dinamis, kreatif dan cerdas. Pernyataan ini berarti bahwa duta wisata umumnya diikuti oleh generasi muda yang memiliki jiwa dan semangat yang positif dalam menjalankan tugasnya. Pernyataan senada juga dijelaskan oleh Randa (2015) bahwa duta wisata merupakan pemuda asli daerah yang berusia 17 tahun hingga 26 tahun yang mempunyai kepedulian terhadap lingkungannya terutama potensi kepariwisataan di daerahnya.

Komunitas Uda Uni Duta Wisata mulai dibentuk sejak tahun 2013 walaupun ajang pemilihan sudah dilakukan sejak tahun 2003. Setiap tahunnya, komunitas ini melakukan ajang pemilihan Uda Uni Duta Wisata untuk mewakili Kota Solok pada perlombaan di tingkat provinsi, serta menyeleksi anggota yang bisa tergabung dalam komunitas ini. Komunitas Duta Wisata Kota Solok memiliki berbagai macam program kerja dalam upaya mempromosikan wisata di Kota Solok. Program tersebut seperti mengadakan festival budaya yang meliputi lomba video promosi wisata 
dan budaya, lomba foto objek wisata, dan lomba fashion show baju adat (baju kurung basiba). Adapun tugas yang harus dilaksanakan setiap tahunnya oleh duta wisata di antaranya: (1) Menjadi perwakilan Kota Solok dalam pemilihan Duta Wisata Sumatera Barat bagi pemenang pertama; (2) Kota Solok dalam pemilihan Duta Wisata Sumatera Barat bagi pemenang pertama; (3) Menjadi icon pariwisata Kota Solok; (4) Turut berpartisipasi dalam kegiatan Dinas Pariwisata Kota Solok; (4) Melakukan bentuk upaya promosi wisata, baik melalui media atau secara langsung; (5) Melaksanakan tugas promosi wisata bersama masyarakat sekitar objek wisata dan kelompok sadar wisata; dan (6) Melakukan promosi wisata kepada lingkungan sekitar.

\section{Karakteristik Individu}

Duta wisata terdiri atas sekelompok individu yang dipilih dengan beberapa kriteria tertentu. Duta wisata dapat tergolong sebagai kelompok sadar wisata dalam suatu daerah karena bertugas untuk mempromosikan wisata. Menurut Ismayanti (2010) terdapat beberapa karakteristik yang dimiliki oleh kelompok sadar wisata yang diklasifikasikan berdasarkan demografi. Lebih lanjut karakteristik duta wisata sebagai kelompok sadar wisata di antaranya usia, tingkat pendidikan, dan pekerjaan. Dalam penelitian ini, karakteristik duta wisata ditambah dengan alamat, angkatan, dan gelar yang dimiliki oleh masing-masing duta wisata sebagai individu.

\section{Kompetensi Duta Wisata}

Duta wisata menjalankan perannya dipengaruhi oleh kompetensi yang terdiri atas pengetahuan (brain), penampilan (beauty), sikap (behavior) dan kemampuan komunikasi (communication skill). Hal ini dijelaskan oleh Randa dan Achnes (2015) bahwa duta wisata merupakan putra putri terbaik daerah yang dijadikan contoh oleh muda/mudi yang mempunyai intelektualitas yang baik, komunikasi, dan penampilan yang menarik ke masyarakat serta memiliki kemampuan menguasai kebudayaan yang ada di daerah tersebut.

\section{Faktor Eksternal Duta Wisata}

Faktor eksternal merupakan pengaruh yang diberikan oleh lingkungan luar seperti kelompok, dan lembaga pemerintah. Pembangunan pariwisata sangat membutuhkan kolaborasi antar aktor dan sumber daya manusia yang berperan. Sumber daya manusia pariwisata mencakup wisatawan atau pelaku wisata (tourist) dan pekerja yang melayani jasa wisata. Masing-masing aktor memiliki hubungan yang saling berhubungan dalam mengembangkan sektor pariwisata. Berdasarkan teori aspek pendukung perkembangan pariwisata oleh Windhyastiti dan Widiawati (2016), bahwa komunitas dan pemerintah merupakan faktor eksternal yang memengaruhi duta wisata dalam menjalankan perannya.

\section{Akselerasi Promosi Wisata}

Duta wisata memiliki peran yang sangat penting dalam kegiatan promosi wisata daerah. Menurut Oktarina (2015), duta wisata berperan sebagai ujung tombak dinas kebudayaan dan pariwisata dalam mempromosikan potensi pariwisata yang ada. Menurut Randa dan Achnes (2015), pemilihan duta wisata diharapkan memiliki peran yang signifikan dalam memperkenalkan pariwisata daerah. Selanjutnya, pemilihan duta wisata diharapkan juga mampu menjadi inspirator dan motivator bagi generasi muda dalam menjalankan peran dan fungsinya di masyarakat. Berdasarkan hasil penelitiannya, peran duta wisata dalam mempromosikan pariwisata dilihat dari frekuensi dan metode komunikasi pemasaran yang terdiri dari sales promotion (penjualan langsung), public relations (hubungan masyarakat), dan word of mouth (informasi dari mulut ke mulut). Frekuensi merupakan acuan pengukuran seberapa sering komunikasi promosi tersebut dilakukan, sedangkan metode merupakan cara dan alat yang digunakan untuk melakukan kegiatan promosi. 


\section{Agrowisata Sawah Solok}

Agrowisata merupakan bentuk kegiatan pariwisata yang memanfaatkan usaha agro sebagai objek wisata (Handayani 2016). Pengembangan agrowisata berbasis potensi lokal dapat memberikan dampak positif bagi warga masyarakat, pemerintah dan juga pihak swasta. Agrowisata Sawah Solok terletak di jalur utama Lintas Sumatra Jalan Hamka, Lukah Pandan Kelurahan KTK Kecamatan Lubuk Sikarah Kota Solok. Awalnya Sawah Solok hanyalah hamparan padi luas yang ditengah-tengahnya berdiri dengan kokoh tulisan SAWAH SOLOK, namun pada tahun 2017 Sawah Solok dijadikan tempat wisata berbasis agro.

\section{METODE PENELITIAN}

\section{Pendekatan dan Metode Penelitian}

Penelitian ini menggunakan pendekatan kuantitatif dan didukung dengan pendekatan kualitatif sebagai penjelasan tambahan dalam hasil penelitian. Pendekatan kuantitatif dilakukan dengan metode survei, yaitu penelitian yang mengambil data dari sebagian unsur populasi (sampel) dengan menggunakan kuesioner sebagai alat pengumpulan data pokok (Effendi \& Tukiran 2012). Pengumpulan data kuantitatif diperoleh dengan menggunakan instrumen utama, yaitu kuesioner yang telah disusun sebelumnya. Pendekatan kuantitatif dilakukan untuk menjawab pertanyaan mengenai analisis kompetensi dan faktor eksternal yang memengaruhi performa duta wisata Kota Solok dalam akselerasi promosi Agrowisata Sawah Solok.

Selanjutnya untuk mendukung pendekatan kuantitatif, maka dilakukan pengambilan data kualitatif. Data kualitatif digunakan untuk memperkaya data dan informasi yang diperoleh. Data kualitatif diperoleh melalui metode wawancara mendalam terhadap informan menggunakan panduan wawancara yang berisikan pertanyaan dan ditujukan kepada informan. Sebelum melakukan penelitian, peneliti melakukan uji coba terhadap kuesioner untuk melihat validitas dan reliabilitas dari kuesioner yang dibuat untuk digunakan oleh peneliti. Uji validitas dan uji reliabilitas dilakukan kepada 10 orang responden penelitian, yaitu anggota duta wisata di daerah selain Kota Solok seperti duta wisata Kabupaten Solok, Kota Padang, dan Kabupaten Lima Puluh Kota.

\section{Lokasi dan Waktu Penelitian}

Penelitian ini dilaksanakan di kawasan Agrowisata Sawah Solok, Kota Solok, Provinsi Sumatera Barat. Pemilihan lokasi dilakukan secara sengaja (purposive) karena merupakan objek wisata andalan yang ada di Kota Solok yang sangat potensial. Adanya pemilihan duta wisata juga menjadi upaya pemerintah, yaitu Dinas Pariwisata Kota Solok untuk meningkatkan pengembangan wisata daerah Kota Solok. Penelitian ini dilaksanakan pada bulan Februari hingga Juli 2021.

\section{Teknik Pemilihan Responden dan Informan}

Penelitian ini memperoleh data dari dua sumber, yaitu responden dan informan. Pemilihan responden pada penelitian ini menggunakan teknik purposive sampling, yaitu pengambilan sampel dengan pertimbangan tertentu yang dianggap relevan atau dapat mewakili objek yang diteliti (Effendi dan Tukiran 2012). Berdasarkan penjajakan dan wawancara singkat dengan ketua komunitas yang dilakukan sebelumnya, populasi pada penelitian ini adalah 113 orang anggota Uda Uni Duta Wisata Kota Solok dari pertama kali komunitas ini dibentuk, yaitu tahun 2013, hingga terakhir kali pemilihan duta wisata dilaksanakan, yaitu tahun 2019.

Pemilihan responden dengan teknik purposive sampling berdasarkan tingkat keaktifan partisipasi anggota duta wisata yaitu 30 orang. Penyebaran anggota duta wisata yang masih aktif di antaranya sebanyak 18 orang dari tahun 2019, 6 orang dari tahun 2018, 4 orang dari tahun 2017 dan sebanyak 2 orang dari anggota angkatan tahun 2016. Sementara anggota duta wisata yang lainnya saat ini 
sudah tidak lagi aktif bertugas karena kesibukan pekerjaan, dan kebanyakan duta wisata yang senior sudah menikah. Pemilihan informan untuk mendapatkan data kualitatif dilakukan secara sengaja (purposive) atau ditentukan. Pihak yang akan menjadi informan adalah stakeholder yang memiliki pengaruh terhadap Uda Uni Duta Wisata Kota Solok. Oleh karena itu, informan dalam penelitian ini di antaranya Dinas Pariwisata Kota Solok, pengelola Agrowisata Sawah Solok, dan masyarakat sekitar yang dapat memberikan informasi terkait peran duta wisata dalam promosi wisata daerah.

\section{Jenis Data dan Teknik Pengumpulan Data}

Penelitian ini mengumpulkan dua jenis data, yaitu data primer dan data sekunder. Data primer pada penelitian ini meliputi kuesioner yang diisi oleh responden dan hasil wawancara kepada informan di lokasi penelitian. Selanjutnya, data sekunder merupakan data yang didapatkan dari sumber di luar kegiatan yang dilakukan di lapangan oleh peneliti. Teknik pengumpulan data menggunakan kuesioner, wawancara mendalam, observasi lapang, studi literatur dan kajian dokumen. Pengumpulan data primer dilakukan melalui kuesioner dan wawancara. Kuesioner dalam penelitian ini disusun dengan pertanyaan yang menggali tentang kompetensi duta wisata, faktor eksternal, dan kegiatan akselerasi promosi Agrowisata Sawah Solok yang dilakukan. Penyebaran kuesioner akan dilakukan secara langsung dan juga secara daring melalui google form kepada 30 orang responden. Hal ini mempertimbangkan efisiensi dalam pengambilan data dan juga kondisi pandemi Covid-19 saat ini. Jawaban dari pertanyaan pada kuesioner berskala ordinal.

Selanjutnya untuk mendukung pendekatan kuantitatif, maka dilakukan pengambilan data kualitatif. Data kualitatif digunakan untuk memperkaya data dan informasi yang diperoleh. Data kualitatif diperoleh melalui metode wawancara mendalam terhadap informan menggunakan panduan wawancara yang berisikan pertanyaan dan ditujukan kepada informan. Informan yang akan diwawancara merupakan stakeholder yang memiliki pengaruh secara langsung ataupun tidak langsung kepada duta wisata. Informan tersebut di antaranya ketua komunitas Uda Uni Duta Wisata Kota Solok, pembina yang juga menjadi bagian dari Dinas Pariwisata Kota Solok, dan pengelola Agrowisata Sawah Solok.

\section{Teknik Pengolahan dan Analisis Data}

Data yang diperoleh pada penelitian ini meliputi data kuantitatif dan data kualitatif. Data kuantitatif diperoleh dari kuesioner yang diisi oleh responden dan selanjutnya diolah menggunakan aplikasi Microsoft Excel 2013 dan IBM SPSS 22. Setelah mendapatkan data, maka data tersebut diinput ke dalam Microsoft Excel 2013 dan dianalisis menggunakan tabel frekuensi, tabulasi silang, dan grafik atau diagram. Selanjutnya, data dianalisis menggunakan uji regresi linear berganda untuk mengukur pengaruh variabel bebas $(x)$ dan variabel terikat $(y)$. Uji ini juga mengukur pengaruh variabel yang melibatkan lebih dari satu variabel bebas (Walpole 1992). Pengolahan data kualitatif melalui tiga tahapan, yaitu reduksi data, penyajian data, dan verifikasi data. Tahap reduksi data merupakan proses pemilihan dan penyederhanaan data hasil wawancara mendalam menjadi data yang terfokus pada objek penelitian (Rijali 2018). 


\section{HASIL DAN PEMBAHASAN}

\section{Karakteristik Responden}

Karakteristik responden meliputi beberapa indikator yang dapat dijelaskan dalam tabel berikut:

Tabel 1 Jumlah dan persentase responden berdasarkan karakteristik individu

\begin{tabular}{|c|c|c|c|c|}
\hline No & $\begin{array}{c}\text { Karakteristik } \\
\text { Internal Responden }\end{array}$ & Kategori & $\begin{array}{l}\text { Jumla } \\
\text { h (n) }\end{array}$ & $\begin{array}{c}\text { Perse } \\
\text { ntase } \\
(\%) \\
\end{array}$ \\
\hline \multirow[t]{3}{*}{1.} & Usia & $18-20$ & 10 & 33.3 \\
\hline & & $21-23$ & 14 & 46.7 \\
\hline & & $>23$ & 6 & 20.0 \\
\hline \multirow[t]{2}{*}{2.} & Jenis Kelamin & Laki-laki & 14 & 46.7 \\
\hline & & Perempuan & 16 & 53.3 \\
\hline \multirow[t]{3}{*}{3.} & Tingkat pendidikan & $\begin{aligned} \text { Rendah } & (\mathrm{SD} \\
\text { sederajat }) & \\
\text { Sedang } & \end{aligned}$ & 0 & 0 \\
\hline & & $\begin{array}{l}\text { (SMP-SMA } \\
\text { sederajat) } \\
\text { Tinggi }\end{array}$ & 21 & 70.0 \\
\hline & & $\begin{array}{l}\text { (Perguruan } \\
\text { tinggi) }\end{array}$ & 9 & 30.0 \\
\hline \multirow[t]{3}{*}{4.} & Jenis Pekerjaan & Karyawan & 4 & 13.3 \\
\hline & & Wirausahawan & 5 & 16.7 \\
\hline & & $\begin{array}{c}\text { Pelajar / } \\
\text { Mahasiswa }\end{array}$ & 21 & 70.0 \\
\hline \multirow[t]{3}{*}{5.} & Lama Tinggal & $<10$ & 3 & 9.9 \\
\hline & & $11-20$ & 16 & 53.4 \\
\hline & & $>21$ & 11 & 36.6 \\
\hline \multirow[t]{4}{*}{6.} & Angkatan & 2016 & 2 & 6.7 \\
\hline & & 2017 & 4 & 13.3 \\
\hline & & 2018 & 6 & 20.0 \\
\hline & & 2019 & 18 & 60.0 \\
\hline \multirow[t]{7}{*}{7.} & Gelar & Finalis & 13 & 43.3 \\
\hline & & Harapan 3 & 4 & 13.3 \\
\hline & & Harapan 2 & 3 & 10.0 \\
\hline & & Harapan 1 & 3 & 10.0 \\
\hline & & Juara 3 & 2 & 6.7 \\
\hline & & Juara 2 & 3 & 10.0 \\
\hline & & Juara 1 & 2 & 6.7 \\
\hline
\end{tabular}

\section{Usia}

Usia adalah lamanya seseorang hidup, terhitung sejak dia dilahirkan hingga saat menjadi responden penelitian dihitung sejak hari kelahiran dan dinyatakan dalam satuan tahun. Responden paling banyak berusia 21 tahun hingga 23 tahun yaitu sejumlah 14 orang sebanyak 26.7 persen. Persyaratan awal pendaftaran untuk menjadi duta wisata memang dibatasi dari usia 17-25 tahun. Oleh karena pemilihan duta wisata terakhir yang dilakukan adalah pada tahun 2019, maka saat ini terdapat enam responden yang berusia lebih dari 23 tahun dengan persentase sebesar 20 persen. 
Selanjutnya, usia responden paling banyak kedua, yaitu berusia dari rentang 18 tahun hingga 20 tahun, yaitu sejumlah 10 orang dengan persentase sebesar 33.3 persen. Rata-rata umur duta wisata yang menjadi responden adalah 21 tahun. Umur responden paling rendah adalah 18 tahun dan umur tertinggi adalah 26 tahun. Berdasarkan data usia responden tersebut, dapat disimpulkan bahwa duta wisata didominasi oleh generasi muda.

\section{Jenis Kelamin}

Jenis kelamin adalah perbedaan antara perempuan dengan laki-laki secara biologis sejak seseorang lahir serta juga menjadi identitas fisik responden yang tercatat dalam kartu identitas. Berdasarkan Tabel 1 terlihat bahwa jumlah responden yang berjumlah 30 orang menurut jenis kelaminnya terbagi menjadi 14 orang laki-laki sebesar 46.7 persen, dan 14 orang perempuan sebesar 53.3 persen. Jumlah dan persentase responden berdasarkan jenis kelamin hanya dibedakan oleh satu orang lebih banyak pada perempuan. Hal ini menunjukkan tidak ada perbedaan yang cukup signifikan berdasarkan jenis kelamin dalam melihat responden yang merupakan duta wisata dengan kategori aktif ketika pengambilan data.

\section{Tingkat Pendidikan}

Tingkat pendidikan adalah jenjang pendidikan formal yang pernah ditempuh oleh responden sampai saat pengambilan data dilaksanakan. Berdasarkan Tabel 1, terlihat jumlah dan persentase responden dengan jumlah terbanyak adalah tingkatan menengah atau SMA sederajat. Responden dengan tingkat pendidikan menengah berjumlah 21 orang dengan persentase sebesar 70.0 persen. Selanjutnya adalah responden lain yang berjumlah 9 orang dengan persentase sebesar 30.0 persen memiliki tingktan pendidikan tinggi atau sudah menamatkan perguruan tinggi. Data juga menunjukkan bahwa tidak ada responden yang memiliki tingkat pendidikan rendah atau SD-SMP sederajat. Hal ini berarti bahwa semua responden telah mengenyam pendidikan sekolah formal.

\section{Jenis Pekerjaan}

Jenis pekerjaan adalah mata pencaharian utama yang dimiliki responden saat pengambilan data dilaksanakan. Berdasarkan Tabel 1, terlihat jumlah dan persentase responden dengan jumlah terbanyak adalah pelajar / mahasiswa sebanyak 21 orang dengan persentase sebesar 70.0 persen. Sementara itu, terdapat lima responden yang memiliki jenis pekerjaan sebagai wirausahawan dewngan persentase sebesar 16.7 persen. Responden yang lain sebanyak 4 orang dengan persentase sebesar 13.3 persen memiliki pekerjaan sebagai karyawan. Hal ini juga berkaitan dengan rentang usia responden yang tergolong kedalam usia dewasa awal atau generasi muda. Jenis pekerjaan akan memberikan pengaruh dalam alokasi waktu responden sebagai duta wisata dalam melaksanakan tugasnya untuk promosi wisata.

\section{Lama Tinggal}

Lama tinggal menurut Wijaksono (2013) adalah jangka waktu domisili seseorang dalam suatu lingkup wilayah tertentu. Berdasarkan Tabel 1 dapat dilihat bahwa waktu lama tinggal responden di Kota Solok paling lama, yaitu lebih dari 21 tahun. Sementara itu, waktu selama kecil dari 10 tahun adalah lama tinggal responden paling singkat. Terdapat tiga responden yang memiliki waktu lama tinggal selama kurang dari 10 tahun. Selanjutnya, sebanyak 11 orang responden memiliki lama tinggal di Kota Solok selama lebih dari 21 tahun. Responden paling banyak memiliki lama tinggal, yaitu pada rentang waktu 11-21 tahun sejumlah 16 orang responden. Perbedaan waktu lama tinggal di Kota Solok pada responden menunjukkan bahwa pemilihan duta wisata Kota Solok memberikan salah satu syarat bahwa peserta merupakan masyarakat Kota Solok walaupun tinggal dengan jangka waktu yang beragam. 


\section{Angkatan}

Angkatan dalam Ikatan Uda Uni Duta Wisata merupakan tahun awal keikutsertaan anggota dimulai saat proses seleksi hingga penobatan gelar menjadi duta wisata. Berdasarkan Tabel 1, terlihat bahwa hingga saat ini duta wisata yang masih aktif berpartisipasi dimulai dari tahun 2016 hingga tahun 2019. Terdapat dua responden yang berasal dari angkatan 2016 dengan persentase sebesar 6.7 persen. Angkatan yang paling baru atau terakhir dilantik yaitu pada tahun 2019 dengan jumlah responen sebanyak 18 orang sebesar 60 persen. Hal yang menyebabkan pemilihan duta wisata masih terhenti di tahun 2019 adalah kondisi pandemi Covid-19 yang menghambat pelaksanaan pemilihan pada tahun 2020 dan 2021. Selanjutnya, terdapat enam orang responden yang berasal dari angkatan 2018 dan empat orang dari angkatan 2017. Dapat dilihat bahwa semakin lama angkatannya maka jumlah duta wisata yang tergolong aktif semakin sedikit. Begitupun sebaliknya, bahwa semakin baru angkatannya, maka duta wisata yang tergolong aktif dan termasuk kategori responden pada penelitian ini juga semakin banyak.

\section{Gelar}

Gelar adalah sebutan kehormatan sebagai bentuk penghargaan atas suatu jasa dan pencapaian kepada seseorang. Dalam Uda Uni Duta Wisata Kota Solok, gelar diberikan kepada semua peserta yang masuk ke tahap karantina dan mengikuti malam puncak. Berdasarkan Tabel 1, jumlah responden terbanyak memiliki gelar sebagai finalis sebanyak 13 orang dengan persentase sebesar 43.3 persen. Selanjutnya, tiga orang responden memiliki masing-masing tingkatan gelar sebangai harapan 2, harapan 1, dan juara 2. Untuk responden dengan tingkatan gelar juara satu hanya terdapat dua orang dengan persentase sebesar 6.7 persen. Hal ini juga disebabkan oleh jumlah pemenang setiap tahunnya yang hanya satu pasang, sementara duta wisata yang menyandang gelar sebagai finalis berjumlah lebih banyak.

\section{Kompetensi Duta Wisata}

Kompetensi duta wisata adalah pengukuran kemampuan duta wisata yang dilihat berdasarkan slogan ajang kecantikan (beauty pageant) yaitu pengetahuan (brain), penampilan (beauty), sikap (behavior) dan kemampuan komunikasi (communication skill). Kompetensi duta wisata dapat dilihat pada tabel berikut: 
Tabel 2 Jumlah dan persentase responden berdasarkan kompetensi duta wisata

\begin{tabular}{|c|c|c|c|c|}
\hline No & $\begin{array}{c}\text { Kompetensi } \\
\text { Duta Wisata }\end{array}$ & Kategori & $\begin{array}{c}\text { Jumlah } \\
\text { (n) }\end{array}$ & $\begin{array}{c}\text { Persentase } \\
(\%)\end{array}$ \\
\hline \multirow[t]{3}{*}{1.} & $\begin{array}{l}\text { Pengetahuan } \\
\text { (brain) }\end{array}$ & Rendah & 7 & 23.3 \\
\hline & & Sedang & 19 & 63.3 \\
\hline & & Tinggi & 4 & 13.3 \\
\hline \multirow[t]{3}{*}{2.} & $\begin{array}{l}\text { Penampilan } \\
\text { (beauty) }\end{array}$ & Rendah & 1 & 3.3 \\
\hline & & Sedang & 9 & 30.0 \\
\hline & & Tinggi & 20 & 66.7 \\
\hline \multirow[t]{3}{*}{3.} & $\begin{array}{l}\text { Sikap } \\
\text { (behavior) }\end{array}$ & Rendah & 1 & 3.3 \\
\hline & & Sedang & 8 & 26.7 \\
\hline & & Tinggi & 21 & 70.0 \\
\hline \multirow[t]{3}{*}{4.} & $\begin{array}{l}\text { Kemampuan } \\
\text { Komunikasi } \\
\text { (communication } \\
\text { skill) }\end{array}$ & Rendah & 0 & 00.0 \\
\hline & & Sedang & 12 & 40.0 \\
\hline & & Tinggi & 18 & 60.0 \\
\hline
\end{tabular}

\section{Pengetahuan (brain)}

Berdasarkan Table 2 Responden sebagian besar memiliki pengetahuan dengan tingkat sedang terhadap Agrowisata Sawah Solok yaitu sejumlah 19 orang dengan persentase sebesar 60.3 persen. Sementara itu, tujuh orang responden memiliki tingkat pengetahuan yang rendah dan sejumlah empat orang responden memiliki tingkat pengetahuan yang tinggi. Beragamnya tingkat pengetahuan responden tentu disebabkan oleh banyak faktor seperti kemampuan daya fikir dan daya ingat masing-masing, rasa ingin tahu yang berbeda dan faktor lainnya.

\section{Penampilan (beauty)}

Berdasarkan Tabel 2, responden sebagian besar memiliki penampilan dengan tingkatan tinggi, yaitu sebanyak 20 orang dengan persentase sebesar 66.7 persen. Sebanyak sembilan responden memiliki penampilan dengan tingkatan sedang yaitu sebesar 30.0 persen. Selanjutnya, satu orang responden memiliki penampilan dengan tingkatan rendah dengan persentase sebesar 3.3 persen. Data tersebut menunjukkan bahwa sebagian besar responden memiliki penampilan yang pantas sebagai duta wisata. Dalam melihat tingkat penampilan, responden diminta untuk menjawab pertanyaan di kuesioner tentang presepsi mengenai keidealan tinggi dan bentuk badan, kemampuan untuk menghias diri, kemampuan untuk menggunakan baju adat, serta penampilan. Pada saat karantina, finalis duta wisata juga mendapatkan kelas menghias diri (make up). Oleh karena itu, dapat disimpulkan bahwa duta wisata yang menjadi responden pada penelitian ini memiliki tingkat penampilan (beauty) yang dominan tinggi.

\section{Sikap (behavior)}


Berdasarkan data pada Tabel 2, terlihat bahwa sebagian besar responden memiliki tingkatan sikap yang tinggi, yaitu sejumlah 21 orang dengan persentase sebesar 70.0 persen. Selanjutnya, sejumlah delapan orang responden dengan persentase sebesar 26.7 persen memiliki tingkatan sikap sendah dan satu orang memiliki tingkatan sikap rendah. Data tersebut menunjukkan bahwa sebagian besar responden yang merupakan duta wisata aktif memiliki sikap yang baik dalam melakukan promosi wisata. Responden memberikan presepsinya terhadap pernyataan mengenai penerimaaan terhadap setiap tugas yang diberikan, perasaan ketika melakukan kegiatan promosi wisata, rasa menghargai antar sesama, presepsi terhadap penugasan yang diberikan, serta perasaan mendalami peran menjadi duta wisata. Oleh karena itu dapat disimpulkan bahwa sikap responden yang merupakan duta wisata dalam promosi wisata cenderung baik.

\section{Kemampuan Komunikasi (communication skill)}

Berdasarkan data pada tabel tersebut, terlihat bahwa sebagian besar responden memiliki tingkatan kemampuan komunikasi (communication skill) cukup dinggi. Hal ini dibuktikan dengan sejumlah 18 responden dengan persentase sebesar 60.0 persen memiliki tingkat kemampuan komunikasi tinggi. Lebih lanjut, tidak ada responden yang memiliki kemampuan komunikasi rendah dan sisanya sejumlah 12 responden dengan persentase sebesar 40.0 persen berada pada kemampuan sedang. Data tersebut merupakan akumulasi skor dari presepsi responden terhadap pernyataan mengenai kemampuan komunikasi dengan pengucapan yang jelas, bahasa yang dikuasai, penggunaan bahasa tubuh, kemampuan berinteraksi, hingga menggunakan media sosial untuk melakukan promosi Agrowisata Sawah Solok.

\section{Faktor Eksternal Duta Wisata}

Faktor eksternal merupakan aspek lain yang memberikan bengaruh kepada akselerasi promosi Agrowisata Sawah Solok selain kompetensi duta wisata. Dalam penelitian ini, faktor eksternal dari duta wisata terdiri atas dukungan dari komunitas duta wisata dan dukungan dari pemerintah lokal. Faktor eksternal duta wisata dapat dilihat pada tabel berikut: 
Tabel 3 Jumlah dan persentase responden berdasarkan faktor eksternal duta wisata

\begin{tabular}{lllcr}
\hline No & $\begin{array}{l}\text { Dinamika } \\
\text { Kelompok }\end{array}$ & Kategori & $\begin{array}{c}\text { Jumlah } \\
(\mathbf{n})\end{array}$ & $\begin{array}{c}\text { Persentase } \\
(\mathbf{\%})\end{array}$ \\
\hline 1. & $\begin{array}{l}\text { Tingkat } \\
\text { Dukungan } \\
\text { Komunitas } \\
\text { Duta } \\
\text { Wisata }\end{array}$ & Rendah & 4 & 13.3 \\
& & & \\
& Sedang & 9 & 30.0 \\
& Tinggi & $\mathbf{1 7}$ & $\mathbf{5 6 . 7}$ \\
& Rendah & & \\
Demerintah & & 1 & 3.3 \\
Lokal & Sedang & 11 & 36.7 \\
& Tinggi & $\mathbf{1 8}$ & $\mathbf{6 0 . 0}$
\end{tabular}

\section{Tingkat Dukungan Komunitas Duta Wisata}

Berdasarkan data tersebut, responden yang memiliki persepsi bahwa dukungan komunitas duta wisata dengan tingkatan tinggi sejumlah 17 orang dengan persentase sebesar 56.7 persen. Terdapat sembilan responden yang memiliki perentase 30 persen pada tingkat sedang dan empat responden dengan persentase 13.3 pada tingkat rendah. Hal ini disebabkan oleh tidak semua anggota aktif duta wisata juga aktif dalam komunitas. Oleh karena itu dapat disimpulkan bahwa tingkat dukungan komunitas duta wisata cukup tinggi.

\section{Tingkat Dukungan Pemerintah Lokal}

Berdasarkan data pada Tabel 3 terlihat bahwa sebanyak 18 orang responden dengan persentase sebesar 60 persen menyatakan bahwa dukungan pemerintah lokal berada pada tingkat yang tinggi. Sementara itu, sejumlah 11 orang responden dengan persentase sebesar 36.7 persen memiliki skor sedang terhadap tingkat dukungan pemerintah lokal dan sisanya adalah tingkat rendah. Responden memberikan persepsi tentang pernyataan yang menggambarkan peran dukungan pemerintah lokal. Pernyataan tersebut di antaranya terkait dengan bentuk pembinaan, penyediaan fasilitas, pemberian insentif, serta dukungan lainnya oleh dinas pariwisata. Oleh karena itu dapat disimpulkan bahwa persepsi responden terhadap frekuensi dukungan pemerintah lokal cukup tinggi.

\section{Akselerasi Promosi Wisata}

Promosi wisata yang dilakukan oleh Uda Uni Duta Wisata Kota Solok menggunakan beberapa metode dalam berbagai kegiatannya. Berdasarkan teori bauran promosi, duta wisata melakukan kegiatan sales promotion, public relation, dan word of mouth. Hasil penelitian akselerasi promosi wisata disajikan pada Tabel 4 dan dideskripsikan sebagai berikut. 
Tabel 4 Jumlah dan persentase responden berdasarkan akselerasi promosi wisata

\begin{tabular}{|c|c|c|c|c|}
\hline No & $\begin{array}{c}\text { Keberlanjutan } \\
\text { Usahatani }\end{array}$ & Kategori & $\begin{array}{c}\text { Jumlah } \\
\text { (n) }\end{array}$ & $\begin{array}{c}\text { Persentase } \\
(\%)\end{array}$ \\
\hline \multirow[t]{4}{*}{1.} & Tingkat & Rendah & & \\
\hline & $\begin{array}{lr}\text { Frekuensi dan } \\
\text { Metode } & \text { Sales } \\
\text { Promotion } & \end{array}$ & & 1 & 3.3 \\
\hline & & Sedang & 13 & 43.3 \\
\hline & & Tinggi & 16 & 53.3 \\
\hline \multirow[t]{4}{*}{2.} & Tingkat & Rendah & & \\
\hline & $\begin{array}{l}\text { Frekuensi } \quad \text { dan } \\
\text { Metode } \\
\text { Relation }\end{array}$ & & 0 & 0 \\
\hline & & Sedang & 11 & 36.7 \\
\hline & & Tinggi & 19 & 63.3 \\
\hline \multirow[t]{4}{*}{3.} & Tingkat & Rendah & & \\
\hline & $\begin{array}{l}\text { Frekuensi Dan } \\
\text { Metode Word of } \\
\text { Mouth }\end{array}$ & & 1 & 3.3 \\
\hline & & Sedang & 17 & 56.7 \\
\hline & & Tinggi & 12 & 40.0 \\
\hline
\end{tabular}

\section{Frekuensi dan Metode Sales Promotion}

Berdasarkan data pada Tabel 4 responden yang memiliki tingkat frekuensi dan metode sales promotion yang tinggi sejumlah 16 orang dengan persentase sebesar 53.3 persen. Selanjutnya, sejumlah 13 orang responden dengan persentase sebesar 43.3 persen memiliki tingkat frekuensi dan metode sales promotion sedang dan satu orang responden pada tingkat rendah. Hal ini menunjukkan secara garis besar kegiatan promosi Agrowisata Sawah Solok melalui sales promotion.

\section{Frekuensi dan Metode Public Relation}

Berdasarkan data pada Tabel 4 sejumlah 19 orang responden memiliki tingkat frekuensi dan metode public relation yang tinggi dengan persentase sebesar 63.3 persen. Selanjutnya, sisa responden yaitu sejumlah 11 orang dengan persentaste sebesar 36.7 persen memiliki tingkat sedang dan tidak ada responden yang memberikan pernyataan dengan tingkatan yang rendah. Responden diberikan pernyataan terkait frekuensi dan metode kegiatan bersama masyarakat, kegiatan bersama dinas terkait, komunitas lainnya, hingga pengurus Agrowisata Sawah Solok. Oleh karena itu dapat disimpulkan bahwa tingkat frekuensi dan metode public relation cukup tinggi.

\section{Frekuensi dan Metode Word of Mouth}

Berdasarkan data pada Tabel 4 sejumlah 12 orang responden memiliki tingkat frekuensi dan metode word of mouth yang tinggi dengan persentase sebesar 40.0 persen. Selanjutnya, sejumlah 17 orang responden dengan persentaste sebesar 56.7 persen memiliki tingkat yang sedang dan satu orang responden dengan tingkat rendah. Responden memberikan pernyataan terkait dengan frekuensi dan metode dalam menceritakan fasilitas di Agrowisata Sawah Solok secara langsung, 
memberikan ulasan di media sosial, serta memberikan rekomendasi untuk berkunjung ke objek wisata tersebut. Oleh karena itu, dapat disimpulkan bahwa frekuensi dan metode word of mouth memiliki tingkatan sedang.

\section{Pengaruh Karakteristik Responden terhadap Akselerasi Promosi Agrowisata Sawah Solok}

Penelitian ini menggunakan uji statistik linear berganda kepada 30 orang responden. Hasil uji ini dapat dijelaskan melalui tabel berikut:

Tabel 5 Hasil uji statistik regresi linear berganda pada pengaruh karakteristik responden terhadap akselerasi promosi Agrowisata Sawah Solok

\begin{tabular}{lrrr}
\hline Variabel & B & T & Sig \\
\hline Usia & -0.218 & -0.635 & 0.532 \\
Jenis & 0.085 & 0.444 & 0.661 \\
Kelamin & & & \\
Tingkat & -0.171 & -0.458 & 0.651 \\
Pendidikan & & & 0.130 \\
Jenis & 0.396 & 1.574 & 0.757 \\
Pekerjaan & & & $\mathbf{0 . 0 2 9}$ \\
Lama & -0.065 & -0.314 & 0.510 \\
Tinggal & $\mathbf{- 0 . 4 9 4}$ & $\mathbf{- 2 . 3 3 8}$ & -0.670 \\
Angkatan & -0.127 & & \\
Gelar & Sig.<0.050. & \\
\hline
\end{tabular}

Keterangan: *Signifikan apabila nilai Sig. $<0.050$.

Berdasarkan nilai Sig dan nilai T pada Tabel 5, dapat dilihat bahwa karakteristik responden yang memiliki pengaruh terhadap akselerasi promosi Agrowisata Sawah Solok adalah angkatan duta wisata. Hal ini dilihat dari nilai signifikan yang didapat adalah angkatan duta wisata sebesar 0.029, dimana nilai tersebut lebih kecil dari nilai probabilitas $5 \%$ atau 0,05 . Nilai T yang didapatkan oleh variabel angkatan duta wisata sebesar 2.338 dimana nilai Thitung tersebut lebih besar dari nilai Ttabel yang didapat, yaitu sebesar 2.074. Dengan demikian, dapat dikatakan bahwa dari variabel karakteristik responden yang mempunyai pengaruh signifikan terhadap akselerasi promosi Agrowisata Sawah Solok adalah angkatan duta wisata.

Untuk mengetahui besar dan arah pengaruh yang dimiliki masing-masing variabel pada karakteristik responden terhadap akselerasi promosi Agrowisata Sawah Solok, dapat dilihat dari nilai koefisien regresi pada kolom B. Nilai koefisien regresi pada angkatan duta wisata sebesar 0.494. Hal ini menunjukkan bahwa semakin besar angkatan duta wisata sebesar satu-satuan, maka akan menaikkan atau menurunkan akselerasi promosi Agrowisata Sawah Solok sebesar 0.494 satu-satuan. Pengaruh yang diberikan angkatan duta wisata terhadap promosi Agriwisata Sawah Solok bernilai positif. Hal ini berarti bahwa semaki tinggi angkatannya maka semakin besar kegiatan promosi wisata yang dilakukan. Pada penelitian ini, angkatan duta wisata paling tinggi adalah tahun 2019. Angkatan 2019 merupakan angkatan terbaru yang sudah dilantik dan sudah menjabat hampir dua tahun karena pada tahun 2020 pemilihan ditiadakan akibat situasi pandemi 
Covid-19. Ikatan Uda Uni Kota Solok memberikan tanggung jawab untuk bertugas kepada duta wisata yang dilantik pada tahun terakhir hingga pemilihan berikutnya. Akan tetapi, sistem ini tidak menutup kemungkinan duta wisata dari angkatan lainnya untuk turut serta berpartisipasi dalam setiap tugas yang ada. Oleh karena itu, hasil analisis statistik ini sesuai dengan data kualitatif berdasarkan wawancara mendalam oleh ketua Ikatan Uda Uni Kota Solok.

\section{Pengaruh Kompetensi Duta Wisata terhadap Akselerasi Promosi Agrowisata Sawah Solok}

Pengujian kompetensi duta wisata terhadap akselerasi promosi Agrowisata Sawah Solok menggunakan uji statistik regresi linear berganda kepada 30 orang responden. Responden diminta untuk memberikan respon sesuai dengan presepsi mereka terkait pernyataan yang ada pada kuesioner. Hasil uji statistik regresi linear berganda digunakan untuk melihat pengaruh kompetensi duta wisata terhadap akselerasi promosi Agrowisata Sawah Solok yang dijelaskan pada tabel berikut:

Tabel 6 Hasil uji statistik regresi linear berganda pada pengaruh kompetensi duta wisata terhadap akselerasi promosi Agrowisata Sawah Solok

\begin{tabular}{lrrr}
\hline Variabel & B & $\mathrm{T}$ & Sig \\
\hline $\begin{array}{c}\text { Pengetahuan } \\
\text { (brain) }\end{array}$ & 0.055 & 0.40 & 0.692 \\
$\begin{array}{c}\text { Penampilan } \\
\text { (beauty) }\end{array}$ & 0.122 & 0.63 & 0.529 \\
Sikap & 8 & \\
(behavior) & 0.192 & 1.08 & 0.290 \\
$\begin{array}{c}\text { Kemampuan } \\
\text { Komunikasi } \\
\text { (communicat }\end{array}$ & $\mathbf{0 . 5 3 2}$ & 0 & \\
ion skill) & & $\mathbf{2 . 5 8}$ & $\mathbf{0 . 0 1 6}$ \\
\end{tabular}

Berdasarkan nilai Sig dan nilai T pada tabel 25, dapat dilihat bahwa kompetensi duta wisata yang memiliki pengaruh terhadap akselerasi promosi Agrowisata Sawah Solok adalah communication skill (kemampuan komunikasi). Hal ini dilihat dari nilai signifikan yang didapat communication skill (kemampuan komunikasi) sebesar 0.016, dimana nilai tersebut lebih kecil dari nilai probabilitas $5 \%$ atau 0,05 . Nilai $\mathrm{T}$ yang didapatkan oleh variabel communication skill (kemampuan komunikasi) sebesar 2.588 dimana nilai Thitung tersebut lebih besar dari nilai Ttabel yang didapat, yaitu sebesar 2.060. Dengan demikian, dapat dikatakan bahwa dari variabel kompetensi duta wisata yang mempunyai pengaruh signifikan terhadap akselerasi promosi Agrowisata Sawah Solok adalah communication skill (kemampuan komunikasi).

Untuk mengetahui besar dan arah pengaruh yang dimiliki masing-masing variabel pada kompetensi duta wisata terhadap akselerasi promosi Agrowisata Sawah Solok, dapat dilihat dari nilai koefisien regresi pada kolom B. Nilai koefisien regresi pada communication skill (kemampuan komunikasi) duta wisata sebesar 0.016. Hal ini menunjukkan bahwa semakin besar communication skill (kemampuan komunikasi) duta wisata sebesar satu-satuan, maka akan menaikkan atau menurunkan akselerasi promosi Agrowisata Sawah Solok sebesar 0.016 satusatuan. Hasil penelitian ini menunjukan bahwa adanya pengaruh kemampuan komunikasi (communication skill) terhadap promosi wisata. Hasil uji analisis statistik ini didukung dengan pernyataan responden yang menyimpulkan bahwa public speaking atau kemampuan komunikasi 
menjadi salah satu faktor penentu keberhasilan duta wisata dalam mempromosikan wisata dalam berbagai bentuk kesempatan.

\section{Pengaruh Faktor Eksternal Duta Wisata terhadap Akselerasi Promosi Agrowisata Sawah Solok}

Faktor eksternal duta wisata merupakan pengaruh yang diberikan oleh lingkungan luar seperti kelompok, dan lembaga pemerintah. Pada penelitian ini, komunitas merujuk pada Ikatan Uda Uni Duta Wisata Kota Solok dan pemerintah lokal adalah Dinas Pariwisata Kota Solok. Pengujian faktor eksternal duta wisata terhadap akselerasi promosi Agrowisata Sawah Solok menggunakan uji statistik regresi linear berganda kepada 30 orang responden yang dapat dijelaskan pada tabel berikut.

Tabel 7 Hasil uji statistik regresi linear berganda pada pengaruh faktor eksternal duta wisata terhadap akselerasi promosi Agrowisata Sawah Solok

\begin{tabular}{lrrr}
\hline Variabel & B & $\mathrm{T}$ & Sig \\
\hline Tingkat & & $\mathbf{2 . 1 8 6}$ & \\
$\begin{array}{l}\text { Dukungan } \\
\text { Komunitas }\end{array}$ & $\mathbf{. 3 5 0}$ & & $\mathbf{0 3 8}$ \\
Tingkat & & & \\
$\begin{array}{l}\text { Dukungan } \\
\text { Pemerintah }\end{array}$ & $\mathbf{. 4 9 8}$ & $\mathbf{3 . 1 1 1}$ & $\mathbf{. 0 0 4}$ \\
Lokal & & & \\
\hline
\end{tabular}

Berdasarkan nilai Sig dan nilai T pada tabel 27, dapat dilihat bahwa semua faktor eksternal duta wisata yang memiliki pengaruh terhadap akselerasi promosi Agrowisata Sawah Solok. Hal ini dilihat dari nilai signifikan tingkat dukungan komunitas duta wisata, yaitu sebesar 0.038, dimana nilai tersebut lebih kecil dari nilai probabilitas $5 \%$ atau 0,05 . Nilai T yang didapatkan oleh variabel tingkat dukungan komunitas duta wisata sebesar 2.186 dimana nilai Thitung tersebut lebih besar dari nilai Ttabel yang didapat, yaitu sebesar 2.052. Selanjutnya, nilai signifikan dari tingkat dukungan pemerintah lokal menunjukkan sebesar 0.004 dimana nilai tersebut lebih kecil dari nilai probabilitas $5 \%$ atau 0,05 . Nilai $\mathrm{T}$ yang didapatkan oleh variabel tingkat dukungan pemerintah lokal adalah 3.111 dimana nilai Thitung tersebut lebih besar dari nilai Ttabel yang didapat, yaitu sebesar 2.052.

Untuk mengetahui besar dan arah pengaruh yang dimiliki masing-masing variabel pada faktor eksternal duta wisata terhadap akselerasi promosi Agrowisata Sawah Solok, dapat dilihat dari nilai koefisien regresi pada kolom B. Nilai koefisien regresi pada tingkat dukungan komunitas duta wisata sebesar 0.038. Hal ini menunjukkan bahwa semakin tinggi tingkat dukungan komunitas duta wisata sebesar satu-satuan, maka akan menaikkan atau menurunkan akselerasi promosi Agrowisata Sawah Solok sebesar 0.038 satu-satuan. Hal yang sama juga berlaku pada tingkat dukungan pemerintah lokal yang memiliki nilai koefisien regresi sebesar 0.004. Pernyataan tersebut berarti bahwa semakin tinggi tingkat dukungan pemerintah lokal akan menaikkan atau menurunkan akselerasi promosi Agrowisata Sawah Solok sebesar 0.004 satu-satuan. 


\section{KESIMPULAN}

Berdasarkan penelitian mengenai Pengaruh Kompetensi Duta Wisata terhadap Akselerasi Promosi Agrowisata Sawah Solok, diperoleh simpulan sebagai berikut: (1) Anggota aktif duta wisata memiliki beberapa karakteristik yang berbeda antar individu. Karakteristik individu yang berpengaruh terhadap akselerasi promosi Agrowisata Sawah Solok adalah angkatan, dimana semakin baru angkatan duta wisata terpilih maka semakin tinggi frekuensi dan metode promosi yang dilakukan; (2) Indikator kompetensi duta wisata yang memiliki pengaruh terhadap akselerasi promosi Agrowisata Sawah Solok adalah kemampuan komunikasi (communication skill); (3) Kedua indikator faktor eksternal duta wisata, yaitu tingkat dukungan komunitas dan tingkat dukungan pemerintah lokal memiliki pengaruh yang signifikan terhadap akselerasi promosi Agrowisata Sawah Solok oleh duta wisata; dan (4) Kegiatan promosi Agrowisata Sawah Solok yang paling sering dilakukan oleh duta wisata diantaranya public relation atau promosi melalui hubungan maryarakat dengan kegiatan sosialnya. Selanjutnya duta wisata juga melakukan upaya promosi melalui metode sales promotion atau menjualan langsung dengan menjadi pemandu wisata, dan mengisi stand di suatu festival. Duta wisata juga mempromosikan Agrowisata Sawah Solok melalui metode word of mouth atau penyampaian informasi dari mulut ke mulut kepada keluarga dan teman-teman mereka.

\section{Saran}

Berdasarkan hasil penelitian, angkatan duta wisata memiliki pengaruh terbesar dibandingkan dengan karakteristik individu lainnya. Hal ini bisa menjadi acuan bagi ketua komunitas dan pembina selaku aktor yang berperan untuk meningkatkan kedekatan antar angkatan. Bagi pemerintah, hasil penelitian ini bisa menjadi referensi untuk penyelenggaraan dalam pemilihan duta wisata selanjutnya. Kemampuan komunikasi sebagai indikator yang paling berpengaruh dibandingkan pengetahuan, sikap, dan penampilan sehingga memiliki kemungkinan untuk dapat menjadi parameter utama dalam penilaian duta wisata.

Komunitas duta wisata dan dukungan pemerintah juga menjadi faktor yang berpengaruh terhadap promosi wisata yang dilakukan oleh duta wisata. Oleh karena itu, komunitas duta wisata disarankan untuk memilih ketua yang kompeten dan melakukan pembagian tugas dengan adil. Pemerintah lokal disarankan dapat memberikan dukungan yang lainnya kepada duta wisata. Perkembangan pariwisata daerah juga tidak bisa lepas dari peran masyarakat. Peneliti mengharapkan bahwa terdapat kerja sama antara duta wisata, pemerintah dan masyarakat untuk bersama-sama memajukan wisata khususnya Agrowisata Sawah Solok.

\section{DAFTAR PUSTAKA}

Agung DP, Wijaya A. 2019. Peran Paguyuban Duta Wisata "Sekargading" dalam Mengembangkan Pariwisata di Kabupaten Batang. Jurnal Sosiologi, Pendidikan dan Pengembangan [internet]. [diunduh pada 2020 Sep 13]. Vol 1 (1) hal: 54-62. Tersedia pada: https://ap3si.org/ojs/index.php/ijsed/article/view/2/7

Effendi S, Tukiran. 2012. Metode Penelitian Survei. Jakarta (ID): LP3ES

Hermansyah. 2011. Kontes Kecantikan dan Eksploitasi Perempuan Dalam Media. Jurnal Perempuan, Agama Dan Gender[internet].[diunduh pada 2 Maret 2021]. 10(2) : 26-38. doi : http://dx.doi.org/10.24014/marwah.v10i2.491

Handayani SM. 2016. Agrowisata Berbasis Usahatani Padi Sawah Tradisional Sebagai Edukasi Pertanian (Studi Kasus Desa Wisata Pentingsari). Jurnal Habitat. [internet]. [Diunduh $\begin{array}{lllllll}\text { pada } 2021 & \text { Feb]. Vol } 27 & \text { (3) hal: 133-138. Tersedia pada : }\end{array}$ https://habitat.ub.ac.id/index.php/habitat/article/view/274/250 
Ismayanti. 2010. Pengantar Pariwisata. Jakarta [ID]: Grasindo.

Melasari K, Yuriewaty P, Waleleng PG. 2017. Peranan Duta Pariwisata Randa Kabilasa dalam Mempromosikan Potensi Wisata Kota Palu. Acta Diurna [internet]. [diunduh pada 2020 Sep 13]. Vol 6 (1) hal: 1-19. Tersedia pada: https://ejournal.unsrat.ac.id/index.php/actadiurnakomunikasi/article/view/15485

Oktarina CA. 2015. Peran Cak dan Ning Surabaya dalam Strategi Promosi Kota Surabaya. Jurnal Komunikasi [internet]. [diunduh pada 2020 Sep 13]. Vol 4 (2) hal: 385-396. Tersedia pada: http://www.journal.unair.ac.id/download-fullpapers-comm377c53110ffull.pdf

Randa R, Achnes S. 2015. Peran Duta Wisata dalam Mempromosikan Pariwisata Kabupaten Solok. Jurnal Ilmu Sosial dan Politik [internet]. [diunduh pada 2020 Sep 13]. Vol 2 (2) hal: 1-11 Tersedia pada: https://media.neliti.com/media/publications/32560-ID-peran- dutawisata-dalam-mempromosikan-pariwisata-kabupaten-solok.pdf

[RI] Republik Indonesia. 2003. Undang-Undang Republik Indonesia Nomor 20 Tahun 2009 tentang Sistem Pendidikan Nasional. Jakarta (ID): Pemerintah RI.__. 2009. UndangUndang Republik Indonesia Nomor 10 Tahun 2009 tentang Kepariwisataan. Jakarta (ID): Pemerintah RI.

Rijali A. 2018. Analisis Data Kualitatif. Jurnal Alhadharah [internet]. [diunduh pada 8 April 2021]. Vol 17 (33): 81-95. Tersedia pada: https://www.researchgate.net/publication/331094976_ANALISIS_DATA_KUALITATIF/li nk/5c657021a6fdccb608c289e8/download

Sari AH. 2016. Kontes Kecantikan: Antara Eksploitasi dan Eksistensi Perempuan. Seminar Nasional Gender \& Budaya Madura Iii Madura: Perempuan, Budaya \& Perubahan [internet]. [diunduh pada 2 Maret 2021]. Tersedia pada: https://ppm.trunojoyo.ac.id/budayamadura/wpcontent /uploads/2016/10/2-11.ARTIKEL.pdf

Walpole RE. 1992. Pengantar Statistik. Jakarta (ID): PT. Gramedia Pustaka Utama

Wijaksono S. 2013. Pengaruh Lama Tinggal terhadap Tingkat Partisipasi Masyarakat dalam Pengelolaan Lingkungan Permukiman. Jurnal Communication and Technology [internet]. [diunduh pada 2021 Jun 30]. Vol 4 (1): 24-32. Tersedia pada: https://media.neliti.com/media/publications/166419-ID-pengaruh-lama-tinggalterhadap-tingkat-p.pdf

Windhyastiti I, Widiawati D. 2016. Pentingnya Aspek Government Power Dalam Pengembangan Industri Pariwisata Daerah. Jurnal Manajemen dan Kewirausahaan. [internet]. [diunduh pada 2020 Nov 25]. Vol 2 (1): 37-44. Tersedia pada: http://jurnal.unmer.ac.id/index.php/jmdk/article/view/405 